\title{
Biological and synthetic scaffold: an extra cellular matrix for constructive tissue engineering
}

\author{
Jaianand $K^{1}$, Hemlata $C^{2}$, Palaniyandi $M^{3}$, Rajangam $B^{4}$, Suriya $S^{5}$, Anubhav $P^{6}$ \\ ${ }^{1}$ Dr. Jaianand Kannaiyan, Head, Clinical Research, ${ }^{2}$ Dr. Hemlata Chhabra, Consultant, Research \& Development, \\ ${ }^{3}$ Dr. Palaniyandi M, Asst. Manager, Tissue Culture, ${ }^{4}$ Mr. Rajangam B, Manager, Tissue Culture, ${ }^{5}$ Mr. Suriya Narayanan \\ S, Head, Lab Operations, ${ }^{6}$ Dr. Anubhav Pandey, Medical Director. All authors are affiliated with CelluGen Biotech \\ Private Limited, Gurgaon, Haryana, India.
}

Address for Correspondence: Dr. Anubhav Pandey, Medical Director, CelluGen Biotech Private Limited, CelluGen House, 62 Udyog Vihar, Phase 1, Gurgaon, Haryana 122016, India. Email: dranubhav.pandey@cellugen.in

\begin{abstract}
Worldwide many people suffering from tissue dysfunctions or damages need rapid transplantation. Tissue engineering has attracted attention as therapeutic modality aiming at repairing lost or damaged tissues. Critical step in tissue engineering is fabrication of three dimensional scaffolds which mimic the extracellular matrix of tissues and promote tissue regeneration process. Extensive research has been carried out to develop a compatible scaffold which mimic the anatomical site of injury and as well as accessing the stem cells and growth factors to home on the injured site. The present article provides an overview on different scaffold approaches and materials used to fabricate scaffolds, with their properties and associated advantages and disadvantages. In particular, the therapeutic potential of amniotic membrane and collagen scaffold has been extensively reviewed in here.
\end{abstract}

Key words: Amniotic membrane, Biological scaffold, Collagen, Synthetic scaffold, Tissue engineering

\section{Introduction}

Organ transplantation- the conventional treatment for tissue defects occurred due to disease, trauma, accident or aging include transplantation of tissue from one site to other from the same individual (autograft) or from other individual (allograft) or from other species (xenograft). Autografts have the problems of donor site morbidity and painful harvesting procedure, while allografts suffer from the immune rejection and dearth of organ donor, highlighting the need for new therapeutic modalities. Tissue engineering and regenerative medicine have come up as expanding approach to overcome the associated limitations with classical approach that aim to repair, reconstruct or improve the function of damaged or diseased tissues with the use of combination of cells, materials and engineering methods. The important triad components in tissue engineering are cells, growth factors and scaffolds. Scaffold is the key component and its function is to act as support on which cells can adhere, proliferate and guide the regeneration of lost tissues. When designing and selecting a scaffold for tissue engineering, there are number of key points to be considered [1,2].

Biocompatibility: The very first criterion for any scaffold to be used in tissue engineering is biocompatibility, that means scaffold should not elicit any responses immunological and histological, and should be easily accepted by body.

Biomimetic: The scaffold should mimic the extracellular matrix of surrounding environment in terms of composition as well architecture where it has going to be implanted. The scaffold should possess cell adhesion sites; so cells can adhere and proliferate well on scaffold.

Manuscript received $5^{\text {th }}$ September 2016

Reviewed: $16^{\text {th }}$ September 2016

Author Corrected: $26^{\text {th }}$ September 2016

Accepted for Publication $10^{\text {th }}$ October 2016 
Biodegradable: The scaffold should be degradable at the rate of new tissue formation obviating the need of scaffold removal. Biodegradability of scaffold allows cells to develop their own extra cellular matrix and repair tissue defects. Furthermore, the byproducts of scaffold degradation also should not be toxic.

Mechanical property: The scaffold should possess mechanical properties similar to implantation sites which protect cells from damaging compressive or tensile forces. The scaffold should have mechanical integrity from the time of implantation to the remodeling process.

Architecture: The architecture of scaffold greatly influences the cellular adhesion and proliferation on scaffold. The scaffold should possess porous structure to facilitate cell infiltration, new tissue formation, nutrients and metabolite transport and gaseous exchange.

Scaffold approaches in tissue engineering: Two major approaches have been evolved in tissue engineering for scaffold fabrication. One is synthetic scaffold in which scaffolds are fabricated using biomaterials. Another is biologic scaffold fabricated with tissues either from allogenic or xenogenic source. Before discussing these approaches in detail, Table 1 highlights the principle and advantages and disadvantages associated with both approaches.

Table-1: Characteristics of synthetic and biologic scaffold approaches.

\begin{tabular}{|c|c|c|}
\hline Scaffold approach & Synthetic scaffold & Biologic scaffold \\
\hline Material choice & $\begin{array}{c}\text { Diversified choice of materials; different } \\
\text { kinds of materials- polymers, ceramic or metal } \\
\text { can be composited together }\end{array}$ & $\begin{array}{c}\text { Allogenic or xenogenic } \\
\text { biological tissue }\end{array}$ \\
\hline Fabrication Technology & A number of fabrication techniques available & Decellularization process \\
\hline Large scale production & Possible & $\begin{array}{c}\text { Depends on availability of tissue } \\
\text { source }\end{array}$ \\
\hline Biomimetic & $\begin{array}{c}\text { Materials and technique selection are critical } \\
\text { steps to make biomimetic scaffold. Different } \\
\text { kind of materials are composited together or } \\
\text { cell adhesion peptide sequence are chemically } \\
\text { added to make biomimetic scaffold }\end{array}$ & $\begin{array}{c}\text { Nature simulating scaffold } \\
\text { Immunogenic }\end{array}$ \\
$\begin{array}{c}\text { Metals, synthetic polymers and their } \\
\text { degradation by products can be immunogenic }\end{array}$ & $\begin{array}{c}\text { Decellularization process } \\
\text { removes xenogenic and allogenic } \\
\text { antigen }\end{array}$ \\
\hline Application & $\begin{array}{c}\text { Scaffolds fabricated with raw chemical } \\
\text { materials; rare chance of any bacterial and } \\
\text { viral infections }\end{array}$ & $\begin{array}{c}\text { Derived from natural source, so } \\
\text { there is risk of disease } \\
\text { transmission }\end{array}$ \\
\hline
\end{tabular}

Synthetic scaffold: The synthetic scaffold approach employs biomaterials to fabricate scaffolds. Key steps in fabrication of synthetic scaffolds are selecting the material and technology that has led to enormous research in developing novel biomaterials and fabrication technology. Various scaffold fabrication technology such as phase separation, porogen leaching, electrospinning, rapid prototyping, injection molding etc. have been developed [3]. In this review we are not concentrating on these technologies and only focusing on properties and different kind of materials used for scaffolding.

Biomaterial is defined as natural or synthetic material that is suitable for introduction into living tissue especially as part of medical device. Enormous choices are available, when selecting the scaffold material. Biomaterials used for scaffold fabrication can be mainly categorized into metals, ceramics, natural and synthetic polymers. Each of these biomaterial groups has certain properties that can be tailored for a particular application [4]. 
Metals: Metallic scaffolds have find applications particularly in load bearing tissues because of their high fatigue resistance and compressive strength. The limitations associated with metals are- poor bioactivity, non-degradable in nature, release of toxic metals.

Ceramics: Ceramics are investigated in different forms such as powdered or granular form, injectable form or as coating on prosthesis. Hydroxyapatite (HA) is one of the widely explored ceramic because of its similarity to mineral phase of bone and osteoconductive nature. Hydroxyapatite containing scaffolds also enhances the differentiation of mesenchymal stem cells towards osteogenic lineage. Ceramics possess advantages of high mechanical stiffness, low elasticity but their brittleness and difficulty in shaping limit their application alone.

Synthetic polymers: A number of synthetic polymers including polycaprolactone (PCL), poly 1-lactic acid (PLLA), poly-lactic- glycolic acid (PLGA), polystyrene, polyglycolic acid (PGA), poly vinyl alcohol (PVA), polyurethane etc. have been explored in different tissue engineering applications. Associated advantages with synthetic polymers are reproducibility, large scale production, tailored mechanical properties, and disadvantages are lack of cell recognition sites, and risk of rejection. The degradation of synthetic polymers is also a concerning issue, as acidic hydrolysis of these polymers cause reduction in $\mathrm{pH}$ of surrounding environment.

Natural polymers: Another class of materials that have attracted attention in artificial scaffold approach is natural polymers having the advantages of cell recognition sites and low antigenicity. Furthermore their biodegradable nature allows host cells to produce their own matrix. However natural polymers suffer from disadvantages like batch to batch variability and poor mechanical property. Table 2 provides glimpse of potential of various materials used in different tissue engineering applications.

Table-2: Different kinds of material explored in tissue engineering

\begin{tabular}{|c|l|l|}
\hline \multicolumn{2}{|c|}{ Synthetic Material } & \multicolumn{1}{c|}{ Applications } \\
\hline \multirow{4}{*}{ Metals } & Titanium & Orthopedic applications, Bone tissue engineering [5-7] \\
\cline { 2 - 3 } & Tantalum & Orthopedic application [8-9] \\
\cline { 2 - 3 } & Iron & Bone Tissue engineering [10-11] \\
\cline { 2 - 3 } & Magnesium & Bone Tissue engineering [12-13] \\
\hline \multirow{4}{*}{ Ceramics } & Hydroxyapatite & Bone tissue engineering [14-19] \\
\cline { 2 - 3 } polymers & Tri calcium phosphate & Bone tissue engineering [20-22] \\
\cline { 2 - 3 } & Bioactive glass & Bone tissue engineering [23-24] \\
\hline \multirow{4}{*}{$\begin{array}{l}\text { Poly caprolactone } \\
\text { (PCL) }\end{array}$} & Bone, skin, vascular tissue engineering, drug delivery [25-30] \\
\cline { 2 - 3 } & $\begin{array}{l}\text { Poly glycolic acid } \\
\text { (PGA) }\end{array}$ & Surgical sutures, bone, skin, vascular tissue engineering [31-34] \\
\cline { 2 - 3 } & $\begin{array}{l}\text { Poly lactic-glycolic acid } \\
\text { (PLGA) }\end{array}$ & Bone, cartilage repair, skin, vascular tissue engineering [35-41] \\
\cline { 2 - 3 } & Polyurethane & Bone, cartilage repair, skin, vascular tissue engineering [42-47] \\
\hline \multirow{5}{*}{ Natural Polymer } & Collagen & Skin, bone, cartilage, blood vessel tissue engineering [48-53] \\
\cline { 2 - 3 } & Gelatin & Skin, bone, cartilage, blood vessel, stem cell delivery [54-59] \\
\cline { 2 - 3 } & Alginate & Drug delivery, Skin, liver tissue engineering [60-62] \\
\cline { 2 - 3 } & Chitosan & Wound healing, skin, bone, cartilage tissue engineering [63-68] \\
\cline { 2 - 3 } & Fibrin & Wound healing, skin ,bone, vascular tissue engineering [69-74] \\
\hline
\end{tabular}

\section{Case Study- Collagen scaffold}

Properties: The most abundant protein in extracellular matrix is collagen and is present in various tissues including blood vessel, bone, cartilage, tendon, ligament, skin etc. Collagen is stable macromolecule comprised of three polypeptide chain woven into triple helix. Major roles of collagen are to maintain the structural integrity of tissues and 
regulate adhesion, migration and proliferation of cells. Collagen possesses poor immunogenic property in comparison to other proteins. The presence of cell recognition peptide sequences on collagen allows cellular adherence and proliferation. Collagen is easily biodegradable in the presence of collagenase enzyme and their degradation profile can be controlled by crosslinking collagen. Low immunogenicity, biocompatibility and biodegradability make it widely explored polymer in tissue engineering and regenerative medicine.

Therapeutic application of Collagen scaffold: Collagen scaffolds can be fabricated in different forms such as thin sheets, sponges, and hydrogels with employing different techniques. To enhance their mechanical stability, collagen scaffold has been prepared by combining it with other polymers and ceramics such as chitosan, gelatin, PCL, PLLA, hydroxyapatite. A large number of in-vitro as well as animal studies have been done with collagen scaffold for various tissue engineering applications, though only some clinical studies are reported with collagen scaffold. Clinical studies done with collagen scaffold have been summarized in Table 3.

Table-3: Therapeutic application of Collagen scaffold: Clinical trials.

\begin{tabular}{|c|c|c|c|}
\hline $\begin{array}{l}\text { Therapeutic } \\
\text { application }\end{array}$ & Collagen scaffold & Author & Results \\
\hline Eye & $\begin{array}{l}\text { Carbodiimide } \\
\text { crosslinked } \\
\text { recombinant human } \\
\text { collagen }\end{array}$ & $\begin{array}{l}\text { Fagerholm P et } \\
\text { al (2014) }\end{array}$ & $\begin{array}{l}\text { Patients grafted with RHC implants had a } 4 \text {-year } \\
\text { average corrected visual acuity of } 20 / 54 \text { and gained } \\
\text { more than } 5 \text { Snellen lines of vision on an eye chart } \\
\text { [75]. }\end{array}$ \\
\hline $\begin{array}{l}\text { Nerve graft } \\
\text { material }\end{array}$ & $\begin{array}{l}\text { Collagen matrix } \\
\text { tubes }\end{array}$ & $\begin{array}{l}\text { Ashley WW Jr } \\
\text { et al (2006) }\end{array}$ & $\begin{array}{l}\text { Four of the five patients experienced a good } \\
\text { recovery, and three exhibited an excellent recovery } \\
\text { at } 2 \text { years postoperatively. The Motor scale } \\
\text { composite was improved by an average of } 69 \text { and } \\
78 \% \text { at } 1 \text { and } 2 \text { years respectively. No complications } \\
\text { were seen [76]. }\end{array}$ \\
\hline $\begin{array}{l}\text { Nerve repairs in } \\
\text { the forearm }\end{array}$ & $\begin{array}{l}\text { Type } 1 \text { collagen } \\
\text { nerve conduits }\end{array}$ & $\begin{array}{l}\text { Dienstknecht } \mathrm{T} \\
\text { et al (2013) }\end{array}$ & $\begin{array}{l}\text { No implant-related complications were observed. } \\
\text { Out of } 9 \text { patients, } 8 \text { patients were satisfied. Collagen } \\
\text { conduits can be an efficacious method for repairing } \\
\text { nerves in forearm [77]. }\end{array}$ \\
\hline $\begin{array}{l}\text { Lingual and } \\
\text { inferior alveolar } \\
\text { nerve injuries }\end{array}$ & $\begin{array}{l}\text { Bioabsorbable } \\
\text { collagen nerve cuff }\end{array}$ & $\begin{array}{l}\text { Farole A et al } \\
(2008)\end{array}$ & $\begin{array}{l}8 \text { out of } 9 \text { nerve repairs exhibited sensory } \\
\text { improvement suggesting role of NeuraGen as a } \\
\text { nerve cuff and protective barrier around the nerve } \\
\text { injury site [78]. }\end{array}$ \\
\hline $\begin{array}{l}\text { Digital nerve } \\
\text { lacerations }\end{array}$ & Collagen conduit & $\begin{array}{l}\text { Taras JJ et al } \\
(2011)\end{array}$ & $\begin{array}{l}\text { Nerve lacerations in } 19 \text { patients were reconstructed } \\
\text { with a bioabsorbable collagen conduit. All patients } \\
\text { recovered protective sensation [79]. }\end{array}$ \\
\hline Endodontics & Collagen scaffold & $\begin{array}{l}\text { Sharma S et al } \\
(2016)\end{array}$ & $\begin{array}{l}\text { Platelet rich fibrin and collagen exhibited better } \\
\text { results than blood clot and PLGA in measurement of } \\
\text { periapical healing, apical closure, and dentinal wall } \\
\text { thickening [80]. }\end{array}$ \\
\hline Cartilage defects & Atelocollagen gel & $\begin{array}{l}\text { Ochi M et al } \\
(2002)\end{array}$ & $\begin{array}{l}\text { Autologous chondrocytes, cultured in atelocollagen } \\
\text { gel were transplanted to patients having full- } \\
\text { thickness defects of cartilage. Transplantation } \\
\text { eliminated locking of the knee and reduced pain and } \\
\text { swelling in all patients [81]. }\end{array}$ \\
\hline $\begin{array}{l}\text { Burns and } \\
\text { Chronic wounds }\end{array}$ & Collagen dressing & $\begin{array}{l}\text { Singh O et al } \\
(2011)\end{array}$ & $\begin{array}{l}\text { Collagen dressed wound exhibited healthy } \\
\text { granulation tissue than conventionally treated } \\
\text { wounds }(\mathrm{P}=0.03) \text {. Collagen-treated patients had } \\
\text { early and more subjective mobility [82]. }\end{array}$ \\
\hline
\end{tabular}


Biological scaffold: Biological scaffold approach employs the scaffolds derived from biological tissues such as extracellular matrix and amniotic membrane. The ECM is derived from various tissues such as blood vessels, skin, nerves, tendon, small intestinal submucosa and amniotic membrane is obtained from placenta during delivery.

Extracellular matrix scaffold consists of complex molecules secreted from resident cells of tissues that are arranged in tissue specific unique 3D structure. The composition of ECM depends on the tissue it has been derived but overall it is a rich source of proteins, proteoglycans and various growth factors. As a scaffold for tissue engineering, ECM not only provides structural support to cells and tissues, but also has growth and signaling factors having angiogenic, chemotactic, antimicrobial properties. Decellularization and sterilization techniques have been developed to produce decellularized low immunogenic sterile ECM scaffolds. Decellularization mainly comprised of mechanical and enzymatic techniques, which remove the xenogenic and allogenic cellular components from the tissues, without compromising the architecture and components of ECM. Extra cellular matrix derived scaffolds have been utilized for different tissue engineering applications including mucoskeleton, cardiovascular, skin tissue engineering etc [83-91].

Case study-Amniotic Membrane (AM): Amniotic membrane derived from placenta possesses a lot of inherent properties which makes it a suitable candidate to be explored as scaffold. The amniotic membrane usage has started since early $20^{\text {th }}$ century, but the advancement in preservation and processing techniques of amniotic membrane has extended its usage largely in last 10 years in reconstructive medicines. The following section deals with properties and therapeutic potential of amniotic membrane in detail.

Anatomy of Amniotic membrane: Amniotic membrane is the innermost thin membrane of placenta which protects the fetus from surrounding environment. The thickness of amniotic membrane varies from 0.02-0.05mm. On microscopic examination, the amniotic membrane consists of three layers- epithelium layer, basement membrane and a vascular stroma. The innermost layer is epithelial layer consisting of single layered of cells arranged on basement membrane. The amniotic membrane derives its nutrition by diffusion process through amniotic fluid, because it does not contain any blood vessels or nerves. With material point of view, amniotic membrane contains three kind of materials- extracellular matrix, cells and molecules. The components which make the architecture of membrane contains-collagen I, III IV, V and VII, hyaluronic, fibronectin, proteoglycans, laminin etc. Majorly two types of cells are present in amniotic membrane- amniotic epithelial cells and amniotic mesenchymal stem cells. The important biomolecules present in AM are fibroblast growth factor, platelet derived growth factor, transforming growth factor-beta, and metalloproteinases [92].

Properties: The amniotic membrane possesses several inherent biological properties which make it a potential candidate as scaffold for various therapeutic potential.

Anti-inflammatory: Several reports available in literature exhibit anti-inflammatory property of amniotic membrane. In a study done by Shimmura et al, monocyte and macrophage cells infiltration were observed in amniotic membrane patches after one week of appliance to ocular surface with corneal epithelial defects [93]. The reduction in inflammation was reported with topical application of culture supernatant from human amniotic epithelial cells to dogs via inhibiting the IL-beta and nitric oxide (NO) production [94].

The anti-inflammatory action is also possessed in amniotic membrane extract also. Various anti-inflammatory and anti angiogenic proteins in amniotic epithelial cells as well in amniotic membrane stroma have been identified by Hao et al [95]. He et al. purified a covalent linked complex of heavy chain of inter alpha inhibitor (HC.HA) with abundant hyaluronan (HA) which is responsible for anti-inflammatory action [96].

Non immunogenic: Non immunogenicity is one of the important properties, the scaffold should possess for transplantation. The amniotic epithelial cells do not express many major histocompatible complexes like human leukocyte antigen (HLA)-A, -B and -DR antigens, while express HLA-G conferring immuno-privileged status to amniotic graft. The function of HLA-G is to induce immune tolerance by acting as ligand for inhibitory receptors present on macrophages. Cryopreserved amniotic membrane is known to possess low immunogenicity in comparison to fresh amniotic membrane due to non-viability of cells on cryopreserved membrane [97]. 
Anti-scarring property: Amniotic membrane possesses anti-scarring action by suppressing transforming growth factor (TGF)-beta signaling pathway [98]. In a study performed by Tseng et al, amniotic membrane matrix reduced expression of transforming growth factor beta isoforms in cultured human corneal and limbal fibroblasts [99].

Anti-angiogenic property: In addition to anti-inflammatory and anti-scarring properties, amniotic membrane also possesses antiangiogenic action. Anti-angiogenic compounds such as endostatin, tissue inhibitor metalloproteases have been identified in amniotic membrane. Delay in graft vascularization occurred with AM transplant after pterygium surgery in comparison to conjuctivital autograft.

Studies exhibited the angiogenic action of amniotic membrane also [100]. Amniotic membrane has side dependent angiogenic and anti-angiogenic property increase in angiogenesis was observed in mesenchymal side up, while decrease in angiogenesis was exhibited in epithelial side up [101].

Antimicrobial activity: One of the important properties of amniotic membrane is its antimicrobial activity. During pregnancy, amniotic membrane's antimicrobial action protects the fetus from any bacterial and fungal infection. The amniotic membrane expresses $\beta$ defensins- antimicrobial peptide, elastase inhibitor, leucocyte proteinase inhibitor, which are component of innate immune system.

Various studies have reported the antimicrobial action of amniotic membrane against many Gram positive and Gram negative bacteria [102-103]. The antimicrobial activity of amniotic membrane is retained even after cryopreservation and freeze drying process [104].

\section{Therapeutic applications of Amniotic membrane:}

Ophthalmology: Since 60 years, amniotic membrane transplantation is being used in ophthalmology. There are two major modes to transplant amniotic membrane- either it can be applied as permanent graft in which it act as substrate for cells to grow or temporary bandage or patch in which it act as covering. Amniotic membrane has been used successfully as surgical graft for wide range of ophthalmic conditions (Table 4).

Amniotic membrane in wound healing: Amniotic membrane has gained much popularity in wound and burns treatments because of its ability to reduce scarring, inflammation and enhance epithelialization and wound healing. Amniotic membrane has found wide application in treating different kinds of wounds including diabetic foot ulcer, varicose ulcer, venous leg ulcer, neuropathic foot ulcers etc [120-125].

Various clinical studies done with amniotic membrane for treatment of different kind of wounds have been summarized in our earlier publication [126].

Other therapeutic application of Amniotic membrane: Various clinical studies have been done with amniotic membrane in periodontics also. First in 1997, Gular et al. studied the use of amniotic membrane for vestibuloplasty in 20 patients [127]. In initial days, patients exhibited edema, higher blood flow, but with time grafted area was completely covered and blood flow was also normal.

The efficacy of amniotic membrane for ridge preservation following tooth extraction was studied by Wallace et al and reported no inflammation and excellent bone quality formed [128]. In pre-malignant lesion leucoplakia, the left buccal mucosa was covered with amniotic membrane graft and defect was restored with out any complications.

In periodontics, amniotic membrane graft has shown its efficiency in treating gingival recession, periodontal intrabony defects [129-132].

Amniotic membrane has also been explored recently for other therapeutic applications such as in cartilage restoration, tendon healing, osteoarthritis, planar fasciitis [133-140]. 
Table-4: Clinical application of Amniotic membrane in different Ophthalmic Conditions

\begin{tabular}{|c|c|c|}
\hline Disease & Authors & Results \\
\hline Infectious Keratitis & $\begin{array}{l}\text { Gicquell JJ et al } \\
\text { (2007) }\end{array}$ & $\begin{array}{l}\text { Amniotic membrane transplantation combined with } \\
\text { topical corticosteroid promoted epithelial healing and } \\
\text { reduced pain in severe bacterial keratitis [105]. }\end{array}$ \\
\hline Infectious Keratitis & Kim JS (2001) & $\begin{array}{l}\text { In infectious corneal ulcer, amniotic membrane } \\
\text { transplantation promoted wound healing and reduced } \\
\text { inflammation [106]. }\end{array}$ \\
\hline Infectious Keratitis & Sheha H et al (2010) & $\begin{array}{l}\text { The transplantation of amniotic membrane actively } \\
\text { promoted wound healing in managing severe infectious } \\
\text { keratitis [107]. }\end{array}$ \\
\hline Cornea Ulceration & $\begin{array}{l}\text { Hanada K et al } \\
\text { (2001) }\end{array}$ & $\begin{array}{l}\text { Multilayered amniotic membrane was effective method } \\
\text { for treatment of deep ulcers of cornea and sclera [108]. }\end{array}$ \\
\hline Corneal perforation, ulcers & $\begin{array}{l}\text { Soloman A et al } \\
(2002)\end{array}$ & $\begin{array}{l}\text { AM transplantation was an effective method for non } \\
\text { traumatic corneal perforations [109]. }\end{array}$ \\
\hline Corneal perforation & $\begin{array}{l}\text { Rodriguez Aries MT } \\
\text { et al (2004) }\end{array}$ & $\begin{array}{l}\text { Multilayer AM was found effective in treating corneal } \\
\text { perforation [110]. }\end{array}$ \\
\hline Cornea Epithelial defect & $\begin{array}{l}\text { Prabhasawant P et al } \\
(2001)\end{array}$ & $\begin{array}{l}\text { AM successfully treated corneal epithelial defect by } \\
\text { promoting epithelial healing and preventing corneal } \\
\text { perforations. No graft rejection was observed [111]. }\end{array}$ \\
\hline Cornea Epithelial defect & Seitz B et al (2009) & $\begin{array}{l}\text { AM transplantation was beneficial for treating persistent } \\
\text { epithelial defects, when applied in sandwitch method } \\
{[112] \text {. }}\end{array}$ \\
\hline Bullous keratopathy & $\begin{array}{l}\text { Stefaniu GL et al } \\
(2014)\end{array}$ & $\begin{array}{l}\text { AM transplantation was efficient in treating oedematous } \\
\text { keratopathy. In } 88 \% \text { of cases, improvement was } \\
\text { observed [113]. }\end{array}$ \\
\hline Bullous keratopathy & $\begin{array}{l}\text { Mrukwa-Kominek E } \\
\text { et al. (2002) }\end{array}$ & $\begin{array}{l}\text { AM transplantation was beneficial in the process of } \\
\text { corneal healing and improved visual activity [114]. }\end{array}$ \\
\hline Limbal stem cell deficiency & $\begin{array}{l}\text { Anderson et al } \\
(2001)\end{array}$ & $\begin{array}{l}\text { AM transplantation was effective to restore stable } \\
\text { corneal epithelium with partial limbal stem cell } \\
\text { deficiency and can be an alternative to limbal autograft } \\
\text { and allograft [115]. }\end{array}$ \\
\hline Limbal stem cell deficiency & Gomes et al (2003) & $\begin{array}{l}\text { AM transplantation was efficient for ocular surface } \\
\text { reconstruction in chemical burns having limbal stem cell } \\
\text { deficiency [116]. }\end{array}$ \\
\hline Pterygium surgery & Katbaab et al (2008) & $\begin{array}{l}\text { AM transplantation is safe and effective method in } \\
\text { primary pterygium surgery with low recurrence rate } \\
{[117] \text {. }}\end{array}$ \\
\hline Conjunctivochalasis & Meller D et al (2000) & $\begin{array}{l}\text { Defects were healed in } 16.5+/-7.3 \text { days. Episodic } \\
\text { epiphora was resolved in } 24 \text { of } 30(83.3 \%) \text { eyes [118]. }\end{array}$ \\
\hline Conjunctivochalasis & $\begin{array}{l}\text { Georgiadis NS et al } \\
(2001)\end{array}$ & $\begin{array}{l}\text { No patient had complain of epiphora and no } \\
\text { conjunctivochalasis was detected in the area in which } \\
\text { human amniotic membrane was transplanted [119]. }\end{array}$ \\
\hline
\end{tabular}

\section{Conclusion}

Critical steps in tissue engineering are selection of material and technology to fabricate scaffold. The main objective of all scaffold fabrication technique is to fabricate scaffold with materials which can mimic the extracellular matrix of targeted tissue as close as possible. The present article has reviewed the properties and therapeutic potential of biological as well as synthetic scaffolds. A wide range of materials including natural, synthetic, ceramic, metals, biological and their composites can be fabricated as scaffold in tissue 
engineering and regenerative medicines and there is continuous research going on to enumerate their full potenitial. Still state- of- the-art synthetic scaffolds has to undergo clinical trials and there is a long way to go from bench to bedside.

However the advancements in processing and preservation technology have enhanced the popularity of biologic scaffolds as graft in various tissue engineering applications. Amniotic membrane provides many advantages over synthetic scaffolds firstly it is available in ample amount at low cost and processing is also very simple. The preservation procedures allow it to store for longer time and use it when required. These preservation procedures also remove the risk of any infection transmission. Furthermore, amniotic membrane being natural material gets easy acceptance from host and there are no reports of graft rejection with amniotic membrane. In addition to biocompatibility, it is permeable, stable, flexible and resorbable with time. Published literature exhibits the wide usage of amniotic membrane in ophthalmology and wound healing and continued to be explored in periodontics, cartilage, tendon etc. However the use of amniotic membrane scaffold for all applications is not possible especially for load bearing application. Further studies are needed to be performed with biological and synthetic scaffolds and their composites to have optimized scaffolds that imitate biological tissues in terms of both structure and function.

Acknowledgement-This work is part of the research programme of CelluGen Biotech Private Limited, Authors would like to express sincere gratitude to Dr. Firdosh Mahuvawala and Mr. Lalit Jaiswal, Directors for making it possible and special thanks to Mr. Anand Bhushan, Chief Operating Officer of Cellugen for encouraging the study.

\section{Funding: Nil, Conflict of interest: None. Permission of IRB: Yes}

\section{References}

1. Chan BP, Leong KW. Scaffolding in tissue engineering: general approaches and tissue-specific considerations. Eur Spine J. 2008 Dec;17 Suppl 4:46779. doi:10.1007/s00586-008-0745-3. Epub 2008 Nov 13.

2. O'Brien FJ. Biomaterials and scaffolds for tissue engineering. Mater today. 2011Mar;14(3):88-95. doi: 10.1016/S1369-7021(11)70058-X.
3. Lu T, Li Y, Chen T. Techniques for fabrication and construction of three-dimensional scaffolds for tissue engineering. Int J Nanomedicine. 2013 Jan;8:337-50. doi: $10.2147 /$ IJN.S38635.

4. Zohora FT. Biomaterials as porous scaffolds for tissue engineering applications: A review. ESJ. 2014 Jul;10(21):186-209.

5. Guneta V, Wang JK, Maleksaeedi S, He ZM, Wong MTC, Choong C. Three Dimensional Printing of Titanium for Bone Tissue Engineering Applications: A Preliminary Study. J Biomim Biomater Biomed Eng. 2011;21:101-15. doi: 10.4028/www.scientific. net/ JBBBE.21.101.

6. Kumar A, Biswas K, Basu B. Hydroxyapatitetitanium bulk composites for bone tissue engineering applications. J Biomed Mater Res A. 2015 Feb; 103(2):791-806. doi: 10.1002/jbm.a.35198.

7. Smith CM, Roy TD, Bhalkikar A, Li B, Hickman JJ, Church KH. Engineering titanium and polycaprolactone construct for a biocompatible interface between the body and artificial limb. Tissue Eng Part A. 2010 Feb;16(2):717-24. doi: 10.1089/ten.TEA.2009.0066.

8. Ruperez E, Manero JM, Riccardi K, Li Y, Aparicio C, Gil FJ. Development of tantalum based scaffold for orthopedic applications produced by space-holder method. Mater Design. 2015 Oct;83:112-9. doi: 10. 1016/ j.matdes.2015.05.067

9. Gordon WJ, Conzemius MG, Birdsall E, Wannemuehler Y, Mallapragada S, Lewallen DG, Yaszemski MJ, O'Driscoll SW. Chondroconductive potential of tantalum trabecular metal. J Biomed Mater Res B Appl Biomater. 2005 Nov;75(2):229-33.

10. Quadbeck P, Hauser R, Kummel K, Standke G, Stephani G, Nies B et al. Iron based cellular metals for degradable synthetic bone replacement. In PM 2010 World Congress PM Biomaterials. 2010; 1-8.

11. Murakami T, Ohara K, Narushima T, Ouchi C. Development of a new method for manufacturing iron foam using gases generated by reduction of iron oxide. Mater Trans. 2007 Sep;48(11):2937-44. doi: 10.2320/ matertrans.MRA2007127.

12. Tan L, Gong M, Zheng F, Zhang B, Yang K. Study on compression behavior of porous magnesium used as bone tissue engineering scaffolds. Biomed Mater. 2009 Feb;4(1):015016. doi: 10.1088/1748-6041/4/1/015016. Epub 2009 Jan 13.

13. Staiger MP, Pietak AM, Huadmai J, Dias G Magnesium and its alloys as orthopedic biomaterials: a review. Biomaterials. 2006 Mar;27(9):1728-34. Epub 2005 Oct 24. 
14. Balno F, Novajra G, Vitale-brovarone C. Bioceramics and scaffolds: A winning combination for tissue engineering. Front Bioeng Biotechnol. 2015 Dec;3(202):1-49. doi: 10.3389/fbioe.2015.00202.

15. Oh S, Oh N, Appleford M, Ong JL. Bioceramics for tissue engineering applications- A review. Am J Biochem Biotechnol. 2006 Feb;2(2):49-56. doi: 10.3844/ajbbsp.2006.49.56.

16. Deville S, Saiz E, Tomsia AP. Freeze casting of hydroxyapatite scaffolds for bone tissue engineering. Biomaterials. 2006 Nov;27(32):5480-9. doi: 10.1016/j.biomaterials.2006.06.028.

17. Gervaso F, Scalera F, Padmanabhan SK. High performance hydroxyapatite scaffolds for bone tissue engineering applications. Int J Appl Ceram Tech. 2012 May;9(3):507-16. doi: 10.1111/j.17447402.2011.02662.x.

18. Tripathi G, Basu B. A porous hydroxyapatite scaffold for bone tissue engineering: Physicomechanical and biological evaluations. Ceram Int. 2012 Jan;38(1):341-9. doi: 10.1016/j.ceramint.2011.07.012.

19. Chen G, Lv Y, Dong C, Yang L. Effect of internal structure of collagen/hydroxyapatite scaffold on the osteogenic differentiation of mesenchymal stem cells. Curr Stem Cell Res Ther. 2015 Mar;10(2):99-108. doi: $10.2174 / 1574888 X 09666140812112631$.

20. Samavedi S, Whittington AR, Goldstein AS. Calcium phosphate ceramics in bone tissue engineering: a review of properties and their influence on cell behavior. Acta Biomater. 2013 Sep;9(9):8037-45. doi: 10.1016/j.actbio.2013.06.014. Epub 2013 Jun 19.

21. Wang P, Zhao L, Liu J, Weir MD, Zhou $\mathrm{X}^{4}$, Xu HH. Bone tissue engineering via nanostructured calcium phosphate biomaterials and stem cells. Bone Res. 2014 Sep;2:14017. doi: 10.1038/boneres.2014.17. eCollection 2014.

22. Haaparanta AM, Haimi S, Ella V, Hopper N, Miettinen S, Suuronen R et al. Porous polylactide/beta tricalcium phosphate composite scaffolds for tissue engineering applications. J Tissue Eng Regen Med. 2010 Jul;4(5):366-73. doi: 10.1002/term. 249.

23. Fu Q, Rahaman MN, Bal BS, Bonewald LF, Kuroki K, Brown RF. Silicate, borosilicate and borate bioactive glass scaffolds with controllable degradation rate for bone tissue engineering applications. II. In vitro and in vivo biological evaluation. J Biomed Mater Res A. 2010 Oct;95(1):172-9. doi: 10.1002/jbm.a.32823.

24. Rahaman MN, Day DE, Bal BS, Fu Q, Jung SB, Bonewald LF, Tomsia AP. Bioactive glass in tissue engineering. Acta Biomater. 2011 Jun;7(6):2355-73. doi: 10.1016/j.actbio.2011.03.016. Epub 2011 Mar 21.

25. Mondal D, Griffith M, Venkatraman SS. Polycaprolactone -based biomaterial for tissue engineering and drug delivery: Current scenario and challenges. Int J Polym Mater Polym Biomater. 2016 Jan; 65(5):255-65. doi:10.1080/00914037. 2015.1103241

26. Tam K, Cheyyatraviendran S, Venugopal J, Biswas A, Choolani M, Ramakrishna S, Bongso A, Fong CY. A nanoscaffold impregnated with human wharton's jelly stem cells or its secretions improves healing of wounds. J Cell Biochem. 2014 Apr;115(4):794-803. doi: 10.1002/jcb.24723.

27. Lou T, Leung M, Wang X, Chang JY, Tsao CT, Sham JG et al. Bi-layer scaffold of chitosan/PCLnanofibrous mat and PLLA-microporous disc for skin tissue engineering. J Biomed Nanotechnol. 2014 Jun;10(6):1105-13. doi: 10.1166/jbn.2014.1793.

28. Williams JM, Adewunmi A, Schek RM, Flanagan CL, Krebsbach PH, Feinberg SE et al. Bone tissue engineering using polycaprolactone scaffolds fabricated via selective laser sintering. Biomaterials. 2005 Aug;26 (23):4817-27. doi: 10.1016/j.biomaterials.2004.11.057.

29. Shin M, Yoshimoto H, Vacanti JP. In vivo bone tissue engineering using mesenchymal stem cells on a novel electrospun nanofibrous scaffold. Tissue Eng. 2004 Jan;10(1-2):33-41. doi: 10.1089/ 107632704322791673.

30. Xu CY, Inai R, Kotaki M, Ramakrishna S. Aligned biodegradable nanofibrous structure: a potential scaffold for blood vessel engineering. Biomaterials. 2004 Feb; 25(5):877-86. doi: 10.1016/S01429612(03)00593-3.

31. Cao H, Kuboyama N. A biodegradable porous composite scaffold of PGA/ $\beta$ TCP for Bone tissue Engineering. Bone. 2010 Feb;46(2):386-95. doi: 10.1016/j.bone.2009.09.031.

32. Sekiya N, Ichioka S, Terada D, Tsuchiya S, Kobayashi H. Efficacy of poly glycolic acid (PGA)/ collagen composite nanofibre scaffold on cell migration and neovascularization in vivo skin defect model. J Plast Surg Hand Surg. 2013 Dec; 47(6):498-502. doi: 10.3109/2000656X.2013.788507.

33. Hajiali H, Shahgasempour S, Naimi-Jamal MR, Peirovi H. Electrospun PGA/Gelatin nanofibrous scaffolds and their potential application in vascular tissue engineering. Int J Nanomed. 2011 Jan;6:2133-41. doi: 10.2147/IJN.S24312. 
34. Matl FD, Zlotnyk J, Obermeier A, Friess W, Vogt $\mathrm{S}$, Buchner $\mathrm{H}$ et al. New anti-infective coatings of surgical sutures based on combination of antiseptics and fatty acids. J Biomater Sci Polym Ed. 2009 Jan; 20(10):1439-49. doi: 10.1163/ $092050609 \times 12457418973107$.

35. Meng ZX, Li HF, Sun ZZ, Zheng W, Zheng YF. Fabrication of mineralized electrospun PLGA and PLGA/gelatin nanofibers and their potential in bone tissue engineering. Mater Sci Eng C Mater Biol Appl. 2013 Mar;33(2):699-706. doi: 10.1016/j. msec.2012.10.021.

36. Zhao $\mathrm{W}$, Li J, Jin $\mathrm{K}$, Liu W, Qiu X, Li C. Fabrication of functional PLGA-based electrospun scaffolds and their applications in biomedical engineering. Mater Sci Eng C Mater Biol Appl. 2016 Feb;59:1181-94. doi: 10.1016/j.msec.2015.11.026.

37. Ru C, Wang F, Pang M, Sun L, Chen R, Sun Y. Suspended, Shrinkage free, electrospun PLGA nanofibrous scaffold for skin tissue engineering. ACS Appl Mater Interfaces. 2015 May; 7(20):10872-7. doi: 10.1021/acsami.5b01953.

38. Chen H, Peng Y, Wu S, Tan LP. Electrospun 3D fibrous scaffolds for chronic wound repair. Materials. 2016 Apr; 9 (4):272. doi: 10.3390/ma9040272.

39. Han J, Lazarovici P, Pomerantz C, Chen X, Wei Y, Lelkes PI. Co-electrospun Blends of PLGA, gelatin, and elastin as potential Non thrombogenic scaffolds for vascular tissue engineering. Biomacromolecules. 2011 Feb;12:399-408. doi: 10.1021/bm101149r.

40. Uematsu K, Hatori K, Ishimoto Y, Yamauchi J, Habata T, Takakura $\mathrm{Y}$ et al. Cartilage regeneration using mesenchymal stem cells and a three dimensional poly-lactic-glycolic acid (PLGA) scaffold. Biomaterials. 2005 Jul;26(20):4273-9. doi: 10.1016/j.biomaterials.2004.10.037.

41. Kampmann A, Lindhorst D, Schumann P, Zimmerer $\mathrm{R}$, Kokemuller H, Rucker $\mathrm{M}$ et al. Additive effect of mesenchymal stem cells and VEGF to vascularization of PLGA scaffolds. Microvas Res. 2013 Nov; 90:71-9. doi: 10.1016/j.mvr.2013.07.006.

42. Janik H, Marzec M. A review: Fabrication of porous polyurethane scaffolds. Mater Sci Eng C Mater Biol Appl. 2015 Mar;48:586-91. doi: 10.1016/j.msec.2014.12.037.

43. Ramrattan NN, Heijkants RG, van Tienen TG, Schouten AJ, Veth RP, Buma P. Assessment of tissue ingrowth rates in polyurethane scaffolds for tissue engineering. Tissue Eng. 2005 Jul-Aug;11(7-8):121223.
44. Ryszkowska JL, Auguscik M, Sheikh A, Boccaccini AR. Biodegradable polyurethane composite scaffolds containing Bioglass for Bone tissue Engineering. Compos Sci Technol. 2010 Nov;70(13):1894-908. 10.1016/j.compscitech.2010.05.011.

45. Dong Z, Li Y, Zou Q. Degradation and biocompatibility of porousnanohydroxyapatite/polyurethane composite scaffold for bone tissue engineering. Appl Surf Sci. 2009 Apr;255(12):6087-91.

doi: 10.1016/j.apsusc.2009.01.083.

46. Phan TT, Lim IJ, Tan EK, Bay BH, Lee ST. Evaluation of cell culture on the polyurethane-based membrane (Tegaderm): implication for tissue engineering of skin. Cell Tissue Bank. 2005;6(2):91-7.

47. Sharifpoor S, Labow RS, Santerre JP. Synthesis and characterization of degradable polar hydrophobic ionic polyurethane scaffolds for vascular tissue engineering applications. Biomacromolecules. 2009 Oct;10 (10):2729-39. doi: 10.1021/bm9004194.

48. AI-Munaiied AA, Plunkett NA, Gleeson JP, Weber $\mathrm{T}$, Jungreuthmayer $\mathrm{C}$, Levingstone $\mathrm{T}$ et al. Development of biomimetic collagen-hydroxyapatite composite scaffold for bone tissue engineering using a SBF immersion technique. J Biomed Mater Res B Appl Biomater. 2009 Aug;90(2):584-91. doi: 10.1002/jbm.b.31320.

49. Chan EC, Kuo S, Kong AM, Morrison WA, Dusting GJ, Mitchell GM et al. Three dimensional collagen scaffold promotes intrinsic vascularization for tissue engineering applications. Plos ONE. 2016 Feb;11(2): e0149799. doi: 10.1371/journal.pone.0149799.

50. Rodrigues CVM, Serricella $\mathrm{P}$, Linhares ABR, Guerdes RM, Borojevic R, Rossi MA et al. Characterization of bovine collagen-hydroxyapatite composite scaffold for bone tissue engineering. Biomaterials. 2003 Dec; 24(27):4987-97. doi: 10.1016/S0142-9612(03)00410-1.

51. Ma L, Gao C, Mao Z, Zhou J, Shen J, Hu X et al. Collagen/chitosan porous scaffolds with improved biostability for skin tissue engineering. Biomaterials. 2003 Nov; 24(26):4833-41. doi: 10.1016/S01429612(03)00374-0.

52. Hoyer B, Bernhardt A, Lode A, Heinemann S, Sewing J, Klinger M. Jellyfish collagen scaffolds for cartilage tissue engineering. Acta Biomater. 2014 Feb;10 (2):883-92. doi: 10.1016/j.actbio.2013.10.022.

53. Yuan T, Zhang L, Li K, Fan H, Fan Y, Liang J et al. Collagen hydrogel as an immunomodulatory scaffold in cartilage tissue engineering. J Biomed Mater Res B 
Appl Biomater. 2014 Feb;102(2):337-44. doi: 10.1002/jbm.b.33011.

Liu X, Smith LA, Hu J, Ma PX. Biomimetic nanofibrous gelatin/apatite composite scaffolds for bone tissue engineering. Biomaterials. 2009 Apr; 30(12):2252-8. doi: 10.1016/j.biomaterials.2008.12.068.

54. Chong EJ, Phan TT, Lim IJ, Zhang YZ, Bay BH, Ramakrishna S et al. Evaluation of electrospun PCL/ Gelatin nanofibrous scaffold for wound healing and dermal layered reconstitution. Acta Biomater. 2007 May; 3(3):321-30. doi: 10.1016/j.actbio.2007.01.002.

55. Liu Y, Chan-Mark MB. Hydrogel based on interpenetrating polymer networks of dextran and gelatin for vascular tissue engineering. Biomaterials. 2009 Jan;30(2):196-207. doi: 10.1016/j.biomaterials.2008.09.041.

56. Morimoto N, Kakudo N, Matsui M, Ogura T, Hara $\mathrm{T}$, Suzuki $\mathrm{K}$ et al. Exploratory clinical trial of combination wound therapy with a gelatin sheet and platelet rich plasma in patients with chronic skin ulcers: study protocol. BMJ Open. 2015 May; 5(5):e007733. doi: 10.1136/bmjopen-2015-007733.

57. Deng T, Huang S, Zhou S, He L, Jin Y. Cartilage regeneration using a novel gelatin-chondriotinhyaluronan hybrid scaffold containing bFGFimpregnated microspheres. J Microencapsul. 2007 Mar;24(2):163-74. doi: 10.1080/02652040701233523.

58. Zhao G, Liu F, Lan S, Li P, Wang L, Kou J et al. Large-scale expansion of Wharton's jelly-derived mesenchymal stem cells on gelatin microbeads, with retention of self-renewal and multipotency characteristics and the capacity for enhancing skin wound healing. Stem cell Res ther. 2015 Mar;6(1)1. doi: 10.1186/s13287-015-0031-3.

59. Sun J, Tan H. Alginate based biomaterials for Regenerative Medicine Applications. Materials. 2013 Mar; 6 (4):1285-309. doi:10.3390/ma6041285.

60. Wu Z, Su X, Xu Y, Kong B, Sun W, Mi S. Bioprinting three dimensional cell-laden tissue constructs with controllable degradadtion. Scientific Reports. 2016 Apr; 6. 24474. doi: 10.1038/srep24474.

61. Dvir-Ginzberg M, Gamlieli-Bonshtein I, Agbaria R, Cohen S. Liver tissue engineering within Alginate scaffolds: Effect of cell seeding density on hepatocyte viability, morphology and function. Tissue Eng. 2003;9(4):757-66. doi: 10.1089/107632703768247430.

62. Pusateri E, McCarthy SJ, Gregory KW, Harris RA, Cardenas L, Mcmanus AT et al. Effect of a chitosanbased hemostatic dressing on blood loss and survival in a model of severe venous hemorrhage and hepatic injury in swine. J Trauma. 2003 Jan;54(1):177-82. doi: 10.1097/01.TA.0000032512.04647.C6.

63. Peng H, Yin Z, Liu H, Chen X, Feng B, Yuan H et al. Electrospun biomimetic scaffold of hydroxyapatite/chitosan supports enhanced osteogenic differentiation of nMSCs. Nanotechnology. 2012 Dec; 23(48):485102. doi: 10.1088/0957-4484/23/48/485102.

64. Boucard N, Viton C, Agay D, Mari E, Roger T, Chancerelle $\mathrm{Y}$ et al. The use of physical hydrogels of chitosan for skin regeneration following third degree burns. Biomaterials. 2007 Aug; 28(24):3478-88. doi: 10.1016/j.biomaterials.2007.04.021.

65. Han CM, Zhang LP, Sun JZ, Shi HF, Zhou J, Gao CY. Application of collagen-chitosan/fibrin glue asymmetric scaffolds in skin tissue engineering. J Zhejiang Univ Sci B. 2010 Jul; 11(7)524-30. doi: 10.1631/jzus.B0900400.

66. Tan H, Chu CR, Payne KA, Marra KG. Injectable in situ forming biodegradable chitosan-hyaluronic acid based hydrogels for cartilage tissue engineering. Biomaterials 2009 May;30:2499-506. doi: 10.1016/j.biomaterials.2008.12.080.

67. Zhu C, Fan D, Duan Z, Xue W, Shang L, Chen F et al. Initial investigation of novel human-like collagen/ chitosan scaffold for vascular tissue engineering. J Biomed Mater Res A. 2009 Jun; 89(3):829-40. doi: 10.1002/jbm.a.32256.

68. Osathanon T, Linnes ML, Rajachar RM, Ratner BD, Somerman MJ, Giachelli CM. Microporous nanofibrous fibrin-based scaffolds for bone tissue engineering. Biomaterials. 2008 Oct; 29 (30):4091-9. doi: 10.1016/j.biomaterials.2008.06.030.

69. Karp JM, Sarraf F, Shoichet MS, Davies JE. Fibrinfilled scaffolds for bone-tissue engineering: An in vivo study. J Biomed Mater Res A. 2004 Oct 1;71(1):162-71.

70. Shaikh FM, Callanan A, Kavanagh EG, Burke PE, Grace PA, Mcgloughlin TM. Fibrin: A natural biodegradable scaffold in vascular tissue engineering. Cells Tissues Organs. 2008 Jun;188 (4):333-46. doi: $10.1159 / 000139772$.

71. Chung E, Rybalko VY, Hsieh PL, Leal SL, Samano MA, Willauer AN, Stowers RS, Natesan S, Zamora DO, Christy RJ, Suggs LJ. Fibrin-based stem cell containing scaffold improves the dynamics of burn wound healing. Wound Repair Regen. 2016 Sep;24(5):810-819. doi: 10.1111/wrr.12459. Epub 2016 Sep 13.

72. Kolehmainen K, Willerth SM. Preparation of 3D fibrin scaffolds for stem cell culture applications. $\mathrm{J}$ Vis Exp. 2012 Mar 2;(61):e3641. doi: 10.3791/3641. 
73. Li Y, Meng H, Liu Y, Lee BP. Fibrin gel as an injectable biodegradable scaffold and cell carrier for tissue engineering. ScientificWorldJournal. 2015;2015:685690. doi: 10.1155/2015/685690. Epub 2015 Mar 17.

74. Fagerholm P, Lagali NS, Ong JA, Merrett K, Jackson WB, Polarek JW et al. Stable corneal regeneration four years after implantation of a cell free recombinant human collagen scaffold. Biomaterials. 2014 Mar; 35(8):2420-7. doi: 10.1016/j.biomaterials.2013.11.079.

75. Ashley WW Jr, Weatherly T, Park TS. Collagen nerve guides for surgical repair of brachial plexus birth injury. J Neurosurg. 2006 Dec;105(6 Suppl):452-6.

76. Dienstknecht T, Klein S, Vykoukal J, Gehmert S, Koller M, Gosau M et al. Type I collagen nerve conduits for median nerve repairs in the forearm. $\mathbf{J}$ Hand Surg Am. 2013 Jun;38(6):1119-24. doi: 10.1016/j.jhsa.2013.03.028.

77. Farole A, Jamal BT. A bioabsorbable collagen nerve cuff (NeuraGen) for repair of lingual and inferior alveolar nerve injuries: a case series. J Oral Maxillofac Surg. 2008 Oct;66(10):2058-62. doi: 10.1016/j.joms.2008.06.017.

78. Taras JS, Jacoby SM, Lincoski CJ. Reconstruction of digital nerves with collagen conduits. J Hand Surg Am. $2011 \quad$ Sep;36 (9):1441-6. doi: 10.1016/j.jhsa.2011.06.009.

79. Sharma S, Mittal N. A comparative evaluation of natural and artificial scaffolds in regenerative endodontics: A clinical study. Saudi Endod J. 2016 Jan;6(1):9-15. doi: 10.4103/1658-5984.171995.

80. Ochi M, Uchio Y, Kawasaki K, Wakitani S, Iwasa J. Transplantation of cartilage like tissue made by tissue engineering in the treatment of cartilage defects of the knee. J Bone Joint Surg Br. 2002 May;84(4):571-8. doi: 10.1302/0301-620X.84B4.11947.

81. Singh O, Gupta SS, Soni M, Moses S, Shukla S, Mathur RK. Collagen dressing versus conventional dressings in Burn and chronic wounds: A retrospective study. J Cutan Aesthet Surg. 2011 Jan;4(1):12-6. doi: 10.4103/0974-2077.79180.

82. Badylak SF, Freytes DO, Gilbert TW. Extracellular matrix as biologic scaffold material: structure and function. Acta Biomater. 2009 Jan;5(1):1-13. doi: 10.1016/j.actbio.2008.09.013.

83. Schmidt CE, Baier JM. Acellular vascular tissues: natural biomaterials for tissue repair and tissue engineering. Biomaterials. 2000 Nov; 21(22):2215-31. doi: 10.1016/S0142-9612(00)00148-4.
84. Uchimura E, Sawa Y, Taketani S, Yamanaka Y, Hara M, Matsuda H. Novel method of preparing acellular cardiovascular grafts by decellularization with poly(ethylene glycol). J Biomed Mater Res A. 2003 Dec; 67(3):834-7. doi: 10.1002/jbm.a.10097.

85. Chen RN, Ho HO, Tsai YT, Sheu MT. Process development of an acellular dermal matrix (ADM) for biomedical applications. Biomaterials. 2004 Jun;25(13):2679-86.

10.1016/j.biomaterials.2003.09.070.

86. Hudson TW, Liu SY, Schmidt CE. Engineering an improved acellular nerve graft via optimized chemical processing. Tissue Eng. 2004 Sep;10(9-10):1346-58. doi: 10.1089/ten.2004.10.1641.

87. Kim BS, Yoo JJ, Atala A. Peripheral nerve regeneration using acellular nerve grafts. J Biomed Mater Res. 2004 Feb;68(2):201-9. doi: 10.1002/jbm.a.10045.

88. Cartmell JS, Dunn MG. Effect of chemical treatment on tendon cellularity and mechanical properties. J Biomed Mater Res. 2000 Jan;49(1):134 $40 . \quad$ doi: 10.1002/(SICI)10974636(200001)49:1<134::AID-JBM17>3.0.CO;2-D.

89. Badylak SF, Tullius R, Kokini K, Shelbourne KD, Klootwyk T, Voytik SL et al. The use of xenogeneic small intestinal submucosa as a biomaterial for Achilles tendon repair in a dog model. J Biomed Mater Res. 1995 Aug;29(8):977-85. doi: 10.1002/jbm.820290809.

90. Kropp BP, Eppley BL, Prevel CD, Rippy MK, Harruff RC, Badylak SF et al. Experimental assessment of small intestinal submucosa as a bladder wall substitute. Urology 1995 Sep;46(3):396-400. doi: 10.1016/S0090-4295(99)80227-1.

91. Niknejad H, Peirovi H, Jorjani M, Ahmadiani A, Ghanavi J, Seifalian AM. Properties of the amniotic membrane for potential use in tissue engineering. Eur Cells Mater. 2008 Apr;15:88-99.

92. Shimmura S, Shimazaki J, Ohasi Y, Tsubota K. Anti inflammatory effects of amniotic membrane transplantation in ocular surface disorders. Cornea. 2001 May; 20(4):408-13.

93. Wichayacoop $\mathrm{T}$, Briksawan $\mathrm{P}$, Tuntivanich $\mathrm{P}$, Yibchok-Anun S. Anti-inflammatory effects of topical supernatant from human amniotic membrane cell culture on canine deep corneal ulcer after human amniotic membrane transplantation. Vet Ophthalmol. 2009 Jan;12(1):28-35. doi: 10.1111/j.14635224.2009.00670.x.

94. Hao Y, Ma DH, Hwang DG, Kim WS, Zhang F. Identification of antiangiogenic and anti-inflammatory 
proteins in human amniotic membrane. Cornea 2000 May;19(3):348-52. doi: 10.1097/00003226-20000500000018 .

95. He H, Li W, Chen SY, Zhang S, Chen Y, Hayashida Y. Suppression of activation and induction of apoptosis in RAW264.7 cells by amniotic membrane extract. Invest Ophthalmol Vis Sci. 2008 Oct;49 (10):4468-75. doi: 10.1167/iovs.08-1781.

96. Hori J, Wang M, Kamiya K, Takahashi H, Sakuragawa N. Immunological characteristics of amniotic epithelium. Cornea. 2006 Dec; 25:S53-8. doi: 10.1097/01.ico.0000247214.31757.5c.

97. Lee SB, Li DQ, Tan DTH, Meller D, Tseng SCG. Suppression of TGF- $\beta$ signaling in both normal conjunctival fibroblasts and pterygial body fibroblasts by amniotic membrane. Curr Eye Res. 2000 Apr; 20(4):325-34. doi: 10.1076/0271-3683(200004)2041$5 \mathrm{FT} 325$.

98. Tseng SCG, Li DQ, Ma X. Suppression of transforming growth factor-beta isoforms, TGF- $\beta$ receptor type II and myofibroblast differentiation in cultured human corneal and limbal fibroblasts by amniotic membrane matrix. J Cell Physiol. 1999 Jun;179(3):325-35. doi: 10.1002/(SICI)10974652(199906)179:3<325::AID-JCP10>3.0.CO;2-X.

99. Koob TJ, Lim JJ, Massee M, Zabek N, Rennert R, Gurtner $G$ et al. Angiogenic properties of dehydrated human amnion/chorion allografts: therapeutic potential of soft tissue repair and regeneration. Vasc Cell. 2014 May;6:10. doi: 10.1186/2045-824X-6-10.

100. Niknejad H, Paeini-Vayghan G, Tehrani FA, Khayat-Khoei M, Peirovi H. Side dependent effects of human amnion on angiogenesis. Placenta. 2013 Apr;34 (4):340-5. doi: 10.1016/j.placenta.2013.02.001.

101. Kjaergaard N, Hein M, Hyttel L, Helmig RB, Schonheyder HC, Uldbjerg $\mathrm{N}$ et al. Antibacterial properties of human amnion and chorion in vitro. Eur $\mathrm{J}$ Obstet Gyn RB. 2001 Feb;94(2):224-9. doi: 10.1016/S0301-2115(00)00345-6.

102. Parthasarathy M, Sasikala R, Gunasekaran P, Raja J. Antimicrobial activity of human amnion and chorionic membrane. J Acad Indus Res. 2014 Mar;2 (10):545-7.

103. Tehrani FA, Ahmadiani A, Niknejad H. The effects of preservation procedures on antibacterial property of amniotic membrane. Cryobiology. 2013 Dec;67(3):293-8. doi: 10.1016/j.cryobiol.2013.08.010.

104. Gicquel JJ, Bejjani RA, Ellies P, Mercie M, Dighiero P. Amniotic membrane transplantation in severe bacterial keratitis. Cornea. 2007 Jan;26(1):2733. doi: 10.1097/ICO.0b013e31802b28df.

105. Kim JS, Kim JC, Hahn TW, Park WC. Amniotic membrane transplantation in infectious corneal ulcer. Cornea. 2001 Oct;20(7):720-6. doi: 10.1097/00003226200110000-00010

106. Sheha H, Liang L, Li J, Tseng SC. Sutureless amniotic membrane transplantation for severe bacterial keratitis. Cornea. 2009 Dec;28(10):1118-23. doi: 10.1097/ICO.0b013e3181a2abad.

107. Hanada K, Shimazaki J, Shimmura S, Tsubota K. Multilayered amniotic membrane transplantation for severe ulceration of the cornea and sclera. Am J Ophthalmol. $2001 \quad$ Mar;131(3):324-31. doi:10.1016/S0002-9394(00)00825-4.

108. Solomon A, Meller D, Prabhasawat P, John T, Espana EM, Steuhl KP et al. Amniotic membrane grafts for nontraumatic corneal perforations, descemetoceles and deep ulcers. Ophthalmol. 2002 Apr;109(4):694703. doi: 10.1016/S0161-6420(01)01032-6.

109. Rodriguez Aries MT, Tourino R, Lopez-Valladares MJ, Gude F. Multilayer amniotic membrane transplantation in the treatment of corneal perforations. Cornea. $2004 \quad$ Aug;23(6):577-83. doi: 10.1097/01.ico.0000121709.58571.12

110. Prabhasawat P, Tesavibul N, Komolsuradej W. Single and Multilayer amniotic membrane transplantation for persistent corneal epithelial defect with and without stromal thinning and perforation. $\mathrm{Br} \mathbf{~}$ Ophthalmol. 2001 Dec;85(12):1455-63. doi: 10.1136/bjo.85.12.1455.

111. Seitz B, Das S, Sauer R, Mena D, HofmannRumelt C. Amniotic membrane transplantation for persistent corneal epithelial defects in eyes after penetrating keratoplasty. Eye 2009 Apr;23(4):840-8. doi: 10.1038 /eye.2008.140.

112. Stefaniu GI, Chiotoroiu SM, Secureanu FA, Purcarea VL, Zemba M. Use of amniotic membrane in bullous keratopathy palliative care. J Med Life. 2014;7(Spec Iss 2):88-91.

113. Mrukwa-Kominek E, Gierek-ciaciura S, Rokitawala I, Szymkowiak M. Use of amniotic membrane transplantation for treating bullous keratopathy. Klin Oczna. 2002;104(1):41-6.

114. Anderson DF, Ellies P, Pires RT, Tseng SC. Amniotic membrane transplantation for partial limbal stem cell deficiency. $\mathrm{Br} \mathrm{J}$ Ophthalmol. 2001 May;85(5):567-75. doi: 10.1136/bjo.85.5.567. 
115. Gomes JA, dos Santos MS, Cunha MC, Mascaro VL, Barros JN, de Sousa LB. Amniotic membrane transplantation for partial and total limbal stem cell deficiency secondary to chemical burn. Ophthalmol. 2003 Mar;110(3):466-73. doi: 10.1016/S01616420(02)01888-2.

116. Katbaab A, Ardekani HA, Khoshniyat H, Hosseini HJ. Amniotic membrane transplantation for primary pterygium surgery. J Ophthalmic Vis Res. 2008 Jan;3(1):23-7.

117. Meller D, Maskin SL, Pires RTF, Tseng SCG. Amniotic membrane transplantation for symptomatic conjunctivochalasis refractory to medical treatments. Cornea. 2000 Nov;19(6):796-803. doi: 10.1097/00003226-200011000-00008.

118. Georgiadis NS, Terzidou CD. Epiphora caused by conjunctivochalasis: treatment with transplantation of preserved amniotic membrane. Cornea. 2001 Aug;20(6):619-21.

119. Escandarlou M, Azimi M, Rabbie S, Rabbit M. The healing effect of Amniotic membrane in burn patients. World J Plast Surg. 2016 Jan;5(1):39-44.

120. Shah AP. Using membrane amniotic membrane allografts in the treatment of neuropathic foot ulcers. J Am Podiatr Med Assoc. 2014 Mar;104(2):198-202. doi: 10.7547/0003-0538-104.2.198.

121. Zelen CM, Serena TE, Denoziere G, Fetterolf DE. A prospective randomized comparative parallel study of amniotic membrane wound graft in the management of diabetic foot ulcers. Int Wound J. 2013 Oct;10 (5):5027. doi: 10.1111/iwj.12097.

122. Hanumanthappa MB, Gopinathan S, Guruprasad RD. Amniotic membrane dressing versus conventional dressing in lower limb varicose ulcer: A prospective comparative study. Int J Biol Med Res. 2012;3 (2):1616-20.

123. Mrugala A, Sui A, Plummer M, Altman I, Papineau E, Frandsen D. Amniotic membrane is a potential regenerative option for chronic non healing wounds: a report of five cases receiving dehydrated human amnion/chorion membrane allograft. Int Wound J. 2016 Aug;13(4):485-92. doi: 10.1111/iwj.12458.

124. Duarte IG, Duval-Araujo I. Amniotic membrane as a biological dressing in infected wound healing in rabbits. Acta Cir Bras. 2014 May;29(5):334-9. doi: 10.1590/S0102-86502014000500008.

125. Kannaiyan J, Suriyanarayana S, Palaniyandi M, Rajangam B, Chhabra H, Pandey A. Amniotic membrane as a scaffold in wound healing and diabetic foot ulcer: an experimental technique and recommendations. Int J Res Med Sci. 2016;4(8):365460. doi: 10.18203/2320-6012.ijrms20162206.

126. Gular R, Ercan MT, Ulutuncel N, Devrim H, Uran $\mathrm{N}$. Measurement of blood flow by the $133 \mathrm{Xe}$ clearance technique to grafts of amnion used in vestibuloplasty. Br J Oral and Maxillofac Surg. 1997 Aug;35(4): 280-3. doi: 10.1016/S0266-4356(97)90048-6.

127. Wallace S. Radiographic and histomorphometric analysis of amniotic allograft tissue in ridge preservation: a case report. The Journal of Implant \& Advanced Clinical Dentistry. 2010;2:49-55.

128. Sikder M, Khan AA, Ferdousi F, Pradhan L, Tareq BH. Reconstruction of oralmucosal defect with Oven Dried Human Amniotic Membrane graft: a case report. Bangladesh Journal of Medical Science. 2010 Jul;9(3):170-3. doi: 10.3329/bjms.v9i3.6480.

129. Sham ME, Sultana N. Biological wound dressing - role of amniotic membrane. Int J Dent Clin. 2011 Aug; 3(3):71-2.

130. Singh H, Singh H. Bioactive amnion as a guided tissue regeneration (GTR) membrane for treatment of isolated gingival recession. A case report. Indian Journal of Dentistry. 2013 Jun;4(2):110-3. doi: 10.1016/j.ijd.2012.12.007.

131. Holtzclaw DJ, Toscano NJ. Amnion-chorion allograft barrier used for guided tissue regeneration treatment of periodontal intrabony defects: a retrospective observational report. Clinic Adv Periodontics. 2013 Aug; 3(3):131-7. doi: 10.1902/cap.2012.110110.

132. Lindenmair A, Nurnberger S, Stadler G, Meinl A, Hackl C, Eibl J et al. Intact human amniotic membrane differentiated towards the chondrogenic lineage. Cell Tissue Bank. 2014 Jun;15(2):213-25. doi: 10.1007/s10561-014-9454-9.

133. Liu PF, Guo L, Zhao DW, Zhang ZJ, Kang K, Zhu $\mathrm{RP}$ et al. Study of human acellular amniotic membrane loading bone marrow mesenchymal stem cells in repair of articular cartilage defect in rabbits. Genet Mol Res. 2014 Sep;13(3):7992-8001. doi: 10.4238/2014.September.29.12.

134. Nogami M, Tsuno H, Koike C, Okabe M, Yoshida $\mathrm{T}$, Seki $\mathrm{S}$ et al. Isolation and characterization of human amniotic mesenchymal stem cells and their chondrogenic differentiation. Transplantation. 2012 Jun; 93(12):1221-8. doi: 10.1097/TP.0b013e3182529b76.

135. Krishnamurithy G, Shilpa PN, Ahmad RE, Sulaiman $\mathrm{S}, \mathrm{Ng} \mathrm{CL}$, Kamarul T. Human amniotic membrane as a chondrocyte carrier vehicle/substrate: in 
vitro study. J Biomed Mater Res A. 2011 Dec 1;99(3):500-6. doi: 10.1002/jbm.a.33184. Epub 2011 Sep 12.

136. Kueckelhaus M, Philip J, Kamel RA, Canseco JA, Hackl F, Kiwanuka E et al. Sustained release of amnion-derived cellular cytokine solution facilitates Achilles tendon healing in rats. Eplasty. 2014 Aug;14:e29.

137. Ozboluk S, Ozkan Y, Ozturk A, Gul N, Ozdemir RM, Yanik K. The effects of human amniotic membrane and periosteal autograft on tendon healing: experimental study in rabbits. J Hand Surg Eur. 2010 May;35 (4):262-8. doi: 10.1177/1753193409337961.
138. Hanselman AE, Tidwell JE, Santrock RD. Cryopreserved human amniotic membrane injection for plantar fasciitis: a randomized, controlled, double-blind pilot study. Foot Ankle Int. 2015 Feb;36(2):151-8. doi: $10.1177 / 1071100714552824$.

139. Zelen CM, Poka A, Andrews J. Prospective, randomized, blinded, comparative study of injectable micronized dehydrated amniotic/chorionic membrane allograft for plantar fasciitis - a feasibility study. Foot Ankle Int. 2013 Oct;34(10):1332-9. doi: $10.1177 / 1071100713502179$.

\section{How to cite this article?}

Jaianand K, Hemlata C, Palaniyandi M, Rajangam B, Suriya S, Anubhav P.Biological and synthetic scaffold: an extra cellular matrix for constructive tissue engineering. Int J Med Res Rev 2016;4(10):1882-1896.doi:10.17511/ijmrr. 2016.i10.27. 